\title{
Can Potamopyrgus antipodarum (Gastropoda) affect the prevalence of Trichobilharzia szidati in Lymnaea stagnalis populations?
}

\author{
Elżbieta Żbikowska ${ }^{1, *}$, Anna Stanicka ${ }^{1}$, Anna Cichy ${ }^{1}$ and Janusz Żbikowski ${ }^{2}$ \\ ${ }^{1}$ Department of Invertebrate Zoology and Parasitology, Faculty of Biological and Veterinary Sciences, Nicolaus Copernicus University in \\ Toruń, Toruń, Poland \\ ${ }^{2}$ Department of Ecology and Biogeography, Faculty of Biological and Veterinary Sciences, Nicolaus Copernicus University in Toruń, \\ Toruń, Poland
}

Received: 11 December 2020 / Accepted: 15 March 2021

\begin{abstract}
Swimmer's itch is an emerging disease caused by bird schistosomes affecting people all over the world. Lymnaeidae - main host snails in Europe - are the source of harmful cercariae of these zoonotic parasites. The aim of this work was to determine whether Polish lakes, inhabited by Potamopyrgus antipodarum (Gray, 1843), result in a lower potential risk of swimmer's itch compared to lakes uninhabited by this non-native snail species. As a result of the dilution effect created by increasing the diversity of cooccurring non-host targets for miracidia, the risk of this zoonosis may be reduced. We studied the prevalence of digenean trematodes in Lymnaea stagnalis (Linnaeus, 1758) populations from 30 water bodies partly inhabited by $P$. antipodarum. The bird schistosome infection in snail hosts was found in five lakes inhabited and 11 lakes uninhabited by the non-native snails. The prevalence of these parasitesin host snail populations in the lakes uninhabited was significantly higher than in lakes inhabited by P. antipodarum. We conclude that $P$. antipodarum seems to be a good potential target for reducing the risk of swimmer's itch via the dilution effect. We expect from our point of view to stimulate a discussion on the use of this species to protect bathing areas against the threat of swimmer's itch.
\end{abstract}

Keywords: Lymnaea stagnalis / bird schistosomes / swimmer's itch / Trichobilharzia szidati / Potamopyrgus antipodarum

\begin{abstract}
Résumé - Potamopyrgus antipodarum (Gastropoda) peut-il affecter la prévalence de Trichobilharzia szidati dans les populations de Lymnaea stagnalis ? Le prurit du nageur est une maladie émergente causée par les schistosomes des oiseaux et qui touche des personnes dans le monde entier. Les Lymnaeidae - principaux escargots hôtes en Europe - sont la source des cercaires nuisibles de ces parasites zoonotiques. Le but de ce travail était de déterminer si les lacs polonais, habités par Potamopyrgus antipodarum (Gray, 1843), entraînent un risque potentiel plus faible de démangeaison du baigneur par rapport aux lacs non habités par cette espèce d'escargot non indigène. Grâce à l'effet de dilution créé par l'augmentation de la diversité des cibles non-hôtes co-occurrentes pour les miracidies, le risque de cette zoonose pourrait être réduit. Nous avons étudié la prévalence des trématodes digéniques dans les populations de Lymnaea stagnalis (Linnaeus, 1758) provenant de 30 plans d'eau partiellement habités par P. antipodarum. L'infection par le schistosome des oiseaux chez les escargots hôtes a été trouvée dans cinq lacs habités et 11 lacs inhabités par les escargots non indigènes. La prévalence de ces parasites dans les populations d'escargots hôtes dans les lacs inhabités était significativement plus élevée que dans les lacs habités par $P$. antipodarum. Nous concluons que $P$. antipodarum semble être une bonne cible potentielle pour réduire le risque de démangeaison du baigneur via l'effet de dilution. Nous espérons de notre point de vue stimuler une discussion sur l'utilisation de cette espèce pour protéger les zones de baignade contre la menace de démangeaisons des baigneurs.
\end{abstract}

Mots clés : Lymnaea stagnalis / schistosomes des oiseaux / prurit du nageur / Trichobilharzia szidati / Potamopyrgus antipodarum

\footnotetext{
*Corresponding author: ezbikow@umk.pl
} 


\section{Introduction}

Our research has focused on how the presence of a nonhost snail species in the environment disturbs the transmission of bird schistosomes (Schistosomatidae, Digenea), zoonotic parasites whose larvae can penetrate the human skin. In the literature, there are numerous reports on the occurrence of a persistently itchy rash known as swimmer's itch (cercarial dermatitis) that appear after penetration of cercariae of parasite species belonging to the genera Trichobilharzia, Bilharziella, Allobilharzia into the skin of people wading in water reservoirs (Żbikowska et al., 2001; Żbikowska, 2004; Jouet et al., 2008; Lawton et al., 2014; Horák et al., 2015; Marszewska et al., 2016; Selbach et al., 2016; Caron et al., 2017; Marszewska et al., 2018; Liberato et al., 2019; Tracz et al., 2019). The attempts to control swimmer's itch on the etiology of bird schistosomes, in particular in Europe and America, are mainly undertaken in bathing areas where omissions regarding biological health hazards may result in economic losses to owners and managers of recreation alplaces (Soldánová et al., 2013). Snails are the target group of organisms against which efforts are directed to reducethe risk of infection (King and Bertsch, 2015). In the life cycle of all schistosomes, including those that infect birds, snails play the role of intermediate hosts and are crucial for the transmission of the parasites (Huot et al., 2020). Host snails are actively infected by ciliated miracidia hatching from the eggs, which find the host by chemoreception. The invasive larva penetrates the snail tegument and transforms inside the host into a mother sporocyst (Allan et al., 2009). In mother sporocysts, daughter sporocysts are formed, and inside them - cercariae invasive for final or accidental hosts develop. The total number of cercariae released from the snail during months of infection reaches values from several to several hundred thousands (Thieltges et al., 2008; Braun et al., 2018). The risk of swimmer's itch depends on the presence of snails infected with bird schistosome larvae in an environment. Even low prevalence (less than 10\%) in snail populations is sufficient for the high risk of cercarial dermatitis (Soldánová et al., 2013). The control of human schistosomiasis is sometimes achieved by exterminating the host snails in the environment (Nelwan, 2019). Apart from the use of molluscicides, the methods of biological control of parasitic infections, such as dilution effect, deserve special attention (Johnson and Thieltges, 2010). Dilution effect means the decrease of infection levels in host population by competitors that reduce the host density. However, opponents of this method emphasize the lack of its universality (Civitello et al., 2015), but followers of introducing non-host species of snails into ecosystems to reduce parasite transmission underline that wherever it brings the expected positive effects - it should be used (Johnson et al., 2009).

\subsection{Community diversity can mediate infection levels and disease}

The choice of the species expected to produce a dilution effect and to decrease the transmission of parasites is crucial. Introduced snails should act as "dead-end" hosts or to be effective competitors for the natural hosts. The choice of some alien species in the controlled areas is one of the proposed ideas (Pointier and Jourdane, 2000).
The issue of the alien species has been one of the most common research trends in the recent literature (Da Silva et al., 2019; Rachalewski, 2019; Arumugam et al., 2020; Jermacz et al., 2020; Kondakov et al., 2020; Larson et al., 2020). The scientific focus on the research concerning the threat to native communities from alien fauna often results in overlooking their potential positive impacts (Goodenough, 2010). An example of an alien species considered to have a negative effect on native communities is the New Zealand mud snail (NZMS) - Potamopyrgus antipodarum (Gray, 1843) (Caenogastropoda, Hydrobioidea, Tateidae) (Brown et al., 2008). However, $P$. antipodarum exhibits parthenogenetic reproduction, resulting in extremely high population density, reaching many thousands of individuals per square meter, and it seems to be a better "dead-end" host for bird schistosomes than native non-host snail species (Brown et al., 1988; Hall et al., 2003; Levri et al., 2007; Davidson et al., 2008). According to these researchers, the species affects the consumption of a large part of primary production in ecosystems. The high effectiveness of $P$. antipodarum in the new areas is due to their high dietary and other phenotypic plasticity, including a generalist diet that comprises periphyton, diatoms, as well as plant and animal detritus. This feature makes this species a very effective competitor of other benthic invertebrates (Levri et al., 2007; Alonso and Castro-Díez, 2008; Brown et al., 2008).

The high population density of $P$. antipodarumas a nonnative species has led some authors to the conclusion that this species contributes to a dangerous change in the community structure of water ecosystems (Gérard et al., 2003; Kerans et al., 2005; Brown et al., 2008; Lysne and Koetsier, 2008). However, it should be noted that the European populations of this species are characterised by large density fluctuations, which significantly reduce their impact on native community. High density followed by local extinction(Moffitt and James, 2012) results from the low genetic diversity of $P$. antipodarum individuals (Dorgelo et al., 2014). The low diversity of $P$. antipodarum haplotypes as a non-native species has also implications for a parasitic invasion (Lively, 1987). Some authors highlighted the probable negative impact of $P$. antipodarum as the host of parasites in new-inhabited ecosystems (Morley, 2008). However, P. antipodarum in its native area is the first intermediate host for at least 20 species of highly host-specific trematode parasitic castrators (Hechinger, 2012), with the prevalence of trematodes varying among the snail populations from $9 \%$ to $80 \%$ (Winterbourn, 1973, 1974; Lively, 1987; King et al., 2011). In the areas outside New Zealand only few cases of the infection with cercariae or metacercariae in the snails have been reported (Larson and Krist, 2020).

Long-term monitoring of the parasitic infection of snails in the lakes of the Polish Lowlands and intensive annual surveys of the $P$. antipodarum populations in the post-mining tanks in Silesia, resulted in finding one individual infected with lophocercariae (Żbikowski and Żbikowska, 2009), five individuals infected with pre-adult forms of Aspidogasterconchicola and 39 snails infected with echinostome metacercariae (Cichy et al., 2017). Additionally, the experimental infection of this snail with the miracidia of Trichobilharzia spp. conducted in our laboratory was unsuccessful (Marszewska et al., 2018, 2020). These data have indicated that the threat concerning the host role of $P$. antipodarum in European waters 


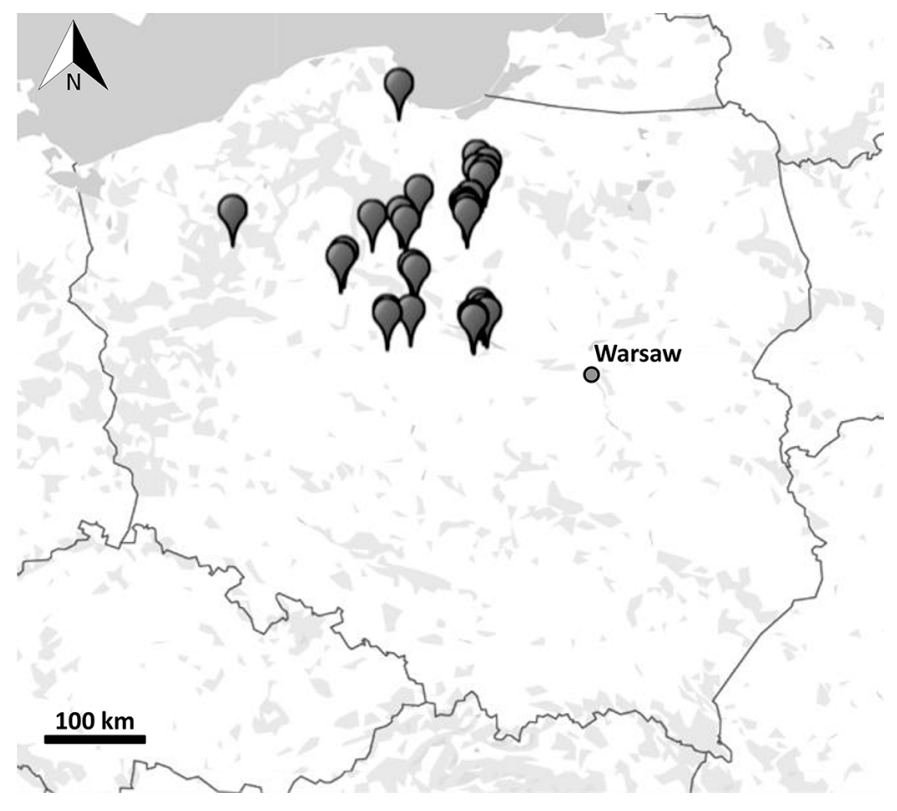

Fig. 1. Map of study lakes in the Polish Lowlands.

(Morley, 2008) is highly exaggerated. The alien species can both negatively and positively affect the native species by influencing parasite-host dynamics and disease occurrence (Kopp and Jokela, 2007; Marszewska et al., 2018; Goedknegt et al., 2019). Moreover, these authors have highlighted that there is surprisingly little research on the impact of the alien species on the parasite infection patterns in the native host communities (Goedknegt et al., 2019). They have also emphasised that the large-scale field studies are favourable for the detailed assessment of the aforementioned mechanism.

As a result ofthedilution effect created by increasing the diversity of co-occurring potential targets, the risk of various parasitic diseases may be reduced (Keesing et al., 2006; Kopp and Jokela, 2007; Cichy et al., 2017). Non-native species (i.e., P. antipodarum) seem to be good potential targets for creating a dilution effect because they lack natural enemies in the habitats.

The aim of this study was to check if there is arelationship between the presence of $P$. antipodarum and the infection of bird schistosomes in Lymnaea stagnalis (Linnaeus, 1758) populations in lakes of Polish Lowland. On the basis of longterm field study, we tested the hypothesis that an alien to Europe, such as $P$. antipodarum, has the potential for abiological control of swimmer's itch in recreational bathing areas.

\section{Material and methods}

\subsection{Snail sampling and laboratory study}

The material used for the parasitological studies were L. stagnalis specimens from 30 lakes in the Polish Lowlands inhabited and uninhabited by P. antipodarum (Fig. 1, SM 1). No empty shells of $P$. antipodarum in lakes uninhabited by this snail indicates that the lack of its individuals was not the result of local extinction (SM 1). Lymnaea stagnalis or $P$. antipodarum were dominant in the malacofauna of the studied sites. Snails, for parasitological diagnostic were collected manually only five times in each lake - from May to September between 2002 and 2019. Along with the acquisition of the malacological material for the parasitological studies, the presence of the invasion of the alien $P$. antipodarum in all sampling locations was verified. For this purpose, a semi-quantitative method was used, which was carried out with a $25 \mathrm{~cm}$ dredge. The samples from the area of $0.25 \mathrm{~m} \times 0.25 \mathrm{~m}$ were taken three times in each lake during each sampling period.

During the snail sampling in most water bodies, the measurements of basic environmental parameters were made applying the MultiLine P4 (WTW) Universal Pocket Sized Meter. The $\mathrm{pH}$, conductivity, water temperature and the oxygen content were measured. The characteristics of the lakes have been presented in Table 1 and SM 1.

A single malacological sample for parasitological diagnostics comprised at least 25 individuals of $L$. stagnalis. All of them were tested by standard procedures according to Blankespoor and Reimink (1991). The species of the recorded cercariae were determined on the basis of the morphological and anatomical characteristics (Cichy and Żbikowska, 2016).

\subsection{Statistical analysis}

The Shannon-Wiener Index (H') was applied to calculate the species diversity of digeneantrematodes in L. stagnalis individuals from the lakes inhabited and uninhabited by P. antipodarum.

Due to strong deviations of our data from the assumption of normality and homoscedascity (high variation at zero density of NZM and lower at its higher densities) non-parametric Spearman correlation coefficient was used to check the relationship between NZMS density and the prevalence of digenean trematodes as well as between NZMS density and the prevalence of bird schistosomes.

The $\chi^{2}$ test of the contingency table was applied to compare the number of the lakes inhabited and uninhabited by $P$. antipodarum in terms of lymnaeid snails infected and non-infected by bird schistosomes. All the analyses were performed with PAST Statistical Software Package version 3.0 (Hammer et al., 2001). Statistical significance was assumed for $p<0.05$.

The term "total infection" was used as a percentage of all L. stagnalis individuals infected with the digenean species in relation to all the individuals collected, whereas the term "prevalence" was used as a percentage of lymnaeid individuals infected with one digenean trematode species collected from one lake.

\section{Results}

In the study, 17 lakes without $P$. antipodarum and 13 lakes with $P$. antipodarum were investigated. A total of 4994 individuals of $L$. stagnalis were collected from all the studied lakes, 2231 and 2763 of which came from the lakes inhabited and uninhabited by $P$. antipodarum, respectively.

Snails infected with digenean trematodes were found in all the lakes, with the total infection of $34.2 \%$. The infection of digenean trematodes in L. stagnalis from the lakes inhabited and uninhabited by $P$. antipodarum ranged from $16.4 \%$ to 
E. Żbikowska et al.: Knowl. Manag. Aquat. Ecosyst. 2021, 422, 15

Table 1. GPS of the sampling area, year of research and physicochemical characteristics of investigated water reservoirs.

\begin{tabular}{|c|c|c|c|c|c|c|c|}
\hline No. & Lake & GPS & Study year & $\begin{array}{l}\text { Temperature } \\
{\left[{ }^{\circ} \mathrm{C}\right] \pm \mathrm{SD}}\end{array}$ & $\mathrm{pH} \pm \mathrm{SD}$ & Oxygen $[\mathrm{mg} / \mathrm{l}] \pm \mathrm{SD}$ & $\begin{array}{l}\text { Conductivity } \\
{[\mu \mathrm{S} / \mathrm{cm}] \pm \mathrm{SD}}\end{array}$ \\
\hline 1 & Bielkowskie & $\begin{array}{l}54^{\circ} 16^{\prime} 16^{\prime \prime} \mathrm{N} \\
18^{\circ} 28^{\prime} 39^{\prime \prime} \mathrm{E}\end{array}$ & 2002 & $20 \pm 3.7$ & $8.4 \pm 0.1$ & $1.9 \pm 0.9$ & $525.2 \pm 10.8$ \\
\hline 2 & Czartek & $\begin{array}{l}53^{\circ} 19^{\prime} 22^{\prime \prime} \mathrm{N} \\
19^{\circ} 21^{\prime} 43^{\prime \prime} \mathrm{E}\end{array}$ & 2008 & $-*$ & $-*$ & $-*$ & $-*$ \\
\hline 3 & Czerwica & $\begin{array}{l}53^{\circ} 43^{\prime} 40^{\prime \prime} \mathrm{N} \\
19^{\circ} 31^{\prime} 08^{\prime \prime} \mathrm{E}\end{array}$ & 2002 & $22.8 \pm 1.9$ & $8.7 \pm 0.2$ & $-*$ & $740.2 \pm 10.8$ \\
\hline 4 & $\begin{array}{l}\text { Bielczyńskie } \\
\text { Głuchowskie }\end{array}$ & $\begin{array}{l}53^{\circ} 12^{\prime} 32^{\prime \prime} \mathrm{N} \\
18^{\circ} 34^{\prime} 03^{\prime \prime} \mathrm{E}\end{array}$ & 2003 & $20.8 \pm 1.8$ & $8.5 \pm 0.2$ & $-*$ & $528.6 \pm 5.7$ \\
\hline 5 & Jelenieckie & $\begin{array}{l}53^{\circ} 16^{\prime} 46^{\prime \prime} \mathrm{N} \\
18^{\circ} 31^{\prime} 04^{\prime \prime} \mathrm{E}\end{array}$ & 2004 & $21.6 \pm 2.7$ & $8.2 \pm 0.2$ & -* & $637.2 \pm 10.3$ \\
\hline 6 & Ostrowąskie & $52^{\circ} 49^{\prime} 46^{\prime \prime} \mathrm{N} 18^{\circ} 42^{\prime} 03^{\prime \prime} \mathrm{E}$ & 2008 & $-*$ & $-*$ & -* & $-^{*}$ \\
\hline 7 & Wielkie Partęczyny & $\begin{array}{l}53^{\circ} 24^{\prime} 48^{\prime \prime} \mathrm{N} \\
19^{\circ} 23^{\prime} 16^{\prime \prime} \mathrm{E}\end{array}$ & 2004 & $22.2 \pm 2.2$ & $8.28 \pm 0.1$ & $2.0 \pm 1.0$ & $323.2 \pm 6.7$ \\
\hline 8 & Pod Zamkiem & $\begin{array}{l}52^{\circ} 25^{\prime} 36^{\prime \prime} \mathrm{N} \\
19^{\circ} 27^{\prime} 22^{\prime \prime} \mathrm{E}\end{array}$ & 2002 & $23 \pm 2.3$ & $8.2 \pm 0.1$ & $2.0 \pm 1.0$ & $536.6 \pm 15.3$ \\
\hline 9 & Popek & $\begin{array}{l}53^{\circ} 19^{\prime} 22^{\prime \prime} \mathrm{N} \\
19^{\circ} 21^{\prime} 17^{\prime \prime} \mathrm{E}\end{array}$ & 2008 & $-*$ & $-*$ & $-^{*}$ & $-^{*}$ \\
\hline 10 & Rudnickie Wielkie & $\begin{array}{l}53^{\circ} 26^{\prime} 04^{\prime \prime} \mathrm{N} \\
18^{\circ} 45^{\prime} 07^{\prime \prime} \mathrm{E}\end{array}$ & 2009 & $20.2 \pm 2.2$ & $8.1 \pm 0.1$ & - & $544.0 \pm 15.2$ \\
\hline 11 & Skulsk & $52^{\circ} 28^{\prime} 00^{\prime \prime} \mathrm{N} 18^{\circ} 19^{\prime} 18^{\prime \prime} \mathrm{E}$ & 2018 & $-*$ & $-*$ & $-*$ & $-*$ \\
\hline 12 & Skulska Wies & $52^{\circ} 28^{\prime} 58^{\prime \prime} \mathrm{N} 18^{\circ} 19^{\prime} 34^{\prime \prime} \mathrm{E}$ & 2018 & $-*$ & $-*$ & -* & -* \\
\hline 13 & Służewskie & $52^{\circ} 51^{\prime} 14^{\prime \prime} \mathrm{N} 18^{\circ} 38^{\prime} 38^{\prime \prime} \mathrm{E}$ & 2018 & $-*$ & $-*$ & -* & $-*$ \\
\hline 14 & Szymbarskie & $53^{\circ} 36^{\prime} 52^{\prime \prime} \mathrm{N} 19^{\circ} 30^{\prime} 39^{\prime \prime} \mathrm{E}$ & 2018 & $-*$ & $-*$ & -* & -* \\
\hline 15 & Tynwałdzkie & $\begin{array}{l}53^{\circ} 39^{\prime} 45^{\prime \prime} \mathrm{N} \\
19^{\circ} 38^{\prime} 05^{\prime \prime} \mathrm{E}\end{array}$ & 2005 & $20.4 \pm 3.0$ & $8.2 \pm 0.2$ & -* & $524.6 \pm 9.4$ \\
\hline 16 & Wysokie Brodno & $\begin{array}{l}53^{\circ} 18^{\prime} 08^{\prime \prime} \mathrm{N} \\
19^{\circ} 21^{\prime} 59^{\prime \prime} \mathrm{E}\end{array}$ & 2008 & $-*$ & $-*$ & -* & -* \\
\hline 17 & Zielone & $\begin{array}{l}53^{\circ} 33^{\prime} 41^{\prime \prime} \mathrm{N} \\
19^{\circ} 36^{\prime} 37^{\prime \prime} \mathrm{E}\end{array}$ & 2002 & $20.4 \pm 1.7$ & $8.0 \pm 0.0$ & -* & $408.6 \pm 11.6$ \\
\hline 18 & Głuszyńskie & $52^{\circ} 29^{\prime} 08^{\prime \prime} \mathrm{N} 18^{\circ} 38^{\prime} 13^{\prime \prime} \mathrm{E}$ & 2018 & $-*$ & $-*$ & -* & $-*$ \\
\hline 19 & Zalew Piechota & $\begin{array}{l}52^{\circ} 25^{\prime} 46^{\prime \prime} \mathrm{N} \\
19^{\circ} 27^{\prime} 20^{\prime \prime} \mathrm{E}\end{array}$ & 2002 & $21.8 \pm 2.8$ & $8.4 \pm 0.1$ & $1.9 \pm 0.9$ & $361.8 \pm 12.6$ \\
\hline 20 & Borówno & $\begin{array}{l}53^{\circ} 14^{\prime} 18^{\prime \prime} \mathrm{N} \\
18^{\circ} 07^{\prime} 35^{\prime \prime} \mathrm{E}\end{array}$ & 2004 & $21.2 \pm 1.5$ & $8.2 \pm 0.1$ & $1.94 \pm 1$ & $599 \pm 13.7$ \\
\hline 21 & Sobiejuskie & $\begin{array}{l}52^{\circ} 54^{\prime} 52^{\prime \prime} \mathrm{N} \\
17^{\circ} 42^{\prime} 52^{\prime \prime} \mathrm{E}\end{array}$ & 2004 & $22.4 \pm 1.5$ & $8.6 \pm 0.1$ & $2.2 \pm 0.9$ & $354.8 \pm 12.8$ \\
\hline 22 & Czarne & $\begin{array}{l}52^{\circ} 26^{\prime} 38^{\prime \prime} \mathrm{N} \\
19^{\circ} 26^{\prime} 31^{\prime \prime} \mathrm{E}\end{array}$ & 2007 & $21.6 \pm 2.3$ & $8.7 \pm 0.1$ & $1.6 \pm 0.6$ & $646.6 \pm 67.9$ \\
\hline 23 & Niskie Brodno & $\begin{array}{l}53^{\circ} 16^{\prime} 26^{\prime \prime} \mathrm{N} \\
19^{\circ} 23^{\prime} 01^{\prime \prime} \mathrm{E}\end{array}$ & 2008 & $-*$ & $-*$ & $-*$ & $-*$ \\
\hline 24 & Bytyń Wielki & $\begin{array}{l}53^{\circ} 16^{\prime} 56^{\prime \prime} \mathrm{N} \\
16^{\circ} 16^{\prime} 54^{\prime \prime} \mathrm{E}\end{array}$ & 2004 & $19.2 \pm 4.3$ & $8.2 \pm 0.1$ & -* & $639.4 \pm 11.7$ \\
\hline 25 & Iławskie & $53^{\circ} 35^{\prime} 41^{\prime \prime} \mathrm{N} 19^{\circ} 37^{\prime} 05^{\prime \prime} \mathrm{E}$ & 2019 & -* & $-*$ & $-*$ & $-*$ \\
\hline 26 & Sendeńskie & $\begin{array}{l}52^{\circ} 30^{\prime} 17^{\prime \prime} \mathrm{N} \\
19^{\circ} 35^{\prime} 29^{\prime \prime} \mathrm{E}\end{array}$ & 2003 & $21.8 \pm 2.3$ & $8.66 \pm 0$ & $2.1 \pm 0.9$ & $653.2 \pm 21.7$ \\
\hline 27 & Górskie & $\begin{array}{l}52^{\circ} 28^{\prime} 36^{\prime \prime} \mathrm{N} \\
19^{\circ} 39^{\prime} 34^{\prime \prime} \mathrm{E}\end{array}$ & 2003 & $22 \pm 2$ & $8.2 \pm 0.1$ & $2.3 \pm 0.8$ & $565.6 \pm 20.5$ \\
\hline 28 & Wąsoskie & $\begin{array}{l}52^{\circ} 56^{\prime} 46^{\prime \prime} \mathrm{N} \\
17^{\circ} 44^{\prime} 55^{\prime \prime} \mathrm{E}\end{array}$ & 2004 & $21.8 \pm 1.8$ & $8.72 \pm 0.1$ & $2.1 \pm 0.9$ & $1,328.8 \pm 23.2$ \\
\hline 29 & Sosno & $\begin{array}{l}53^{\circ} 20^{\prime} 14^{\prime \prime} \mathrm{N} \\
19^{\circ} 20^{\prime} 56^{\prime \prime} \mathrm{E}\end{array}$ & 2008 & $-*$ & $-*$ & -* & $-*$ \\
\hline 30 & Soczewka & $\begin{array}{l}52^{\circ} 32^{\prime} 26^{\prime \prime} \mathrm{N} \\
19^{\circ} 33^{\prime} 44^{\prime \prime} \mathrm{E}\end{array}$ & 2003 & $21.2 \pm 2$ & $8.4 \pm 0.1$ & $2.2 \pm 0.9$ & $444.4 \pm 8.8$ \\
\hline
\end{tabular}

* no data. 
E. Żbikowska et al.: Knowl. Manag. Aquat. Ecosyst. 2021, 422, 15

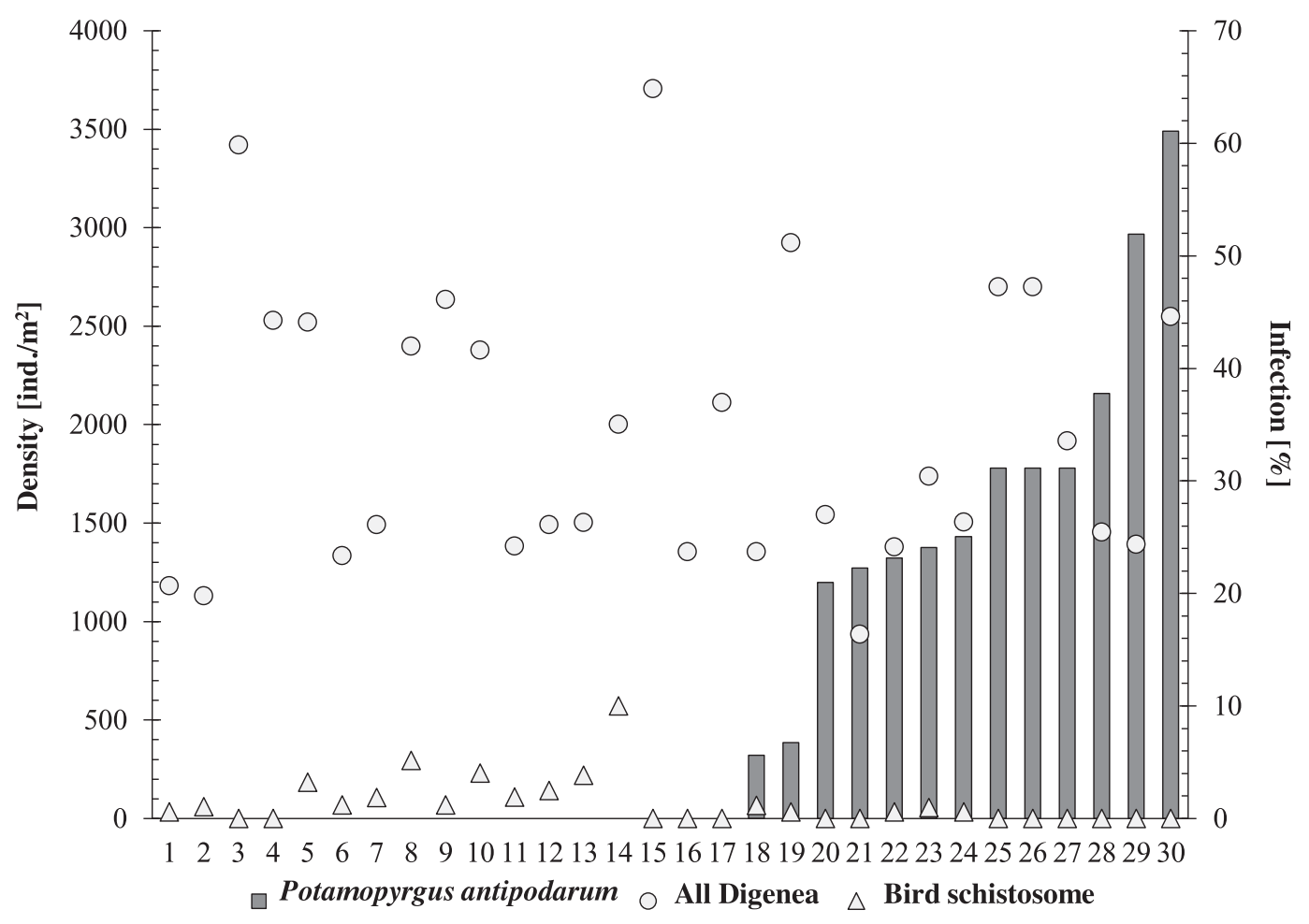

Fig. 2. Potamopyrgus antipodarum population density, total infection and bird schistosome prevalence in Lymnaea stagnalis populations at sampling sites in lakes: 1-Bielkowskie, 2-Czartek, 3-Czerwica, 4-BielczyńskieGłuchowskie, 5-Jelenieckie, 6-Ostrowąskie, 7-WielkiePartęczyny, 8-Pod Zamkiem, 9-Popek, 10-RudnickieWielkie, 11-Skulsk, 12-SkulskaWies, 13-Służewskie, 14-Szymbarskie, 15-Tynwałdzkie, 16-WysokieBrodno, 17-Zielone, 18-Głuszyńskie, 19-ZalewPiechota, 20-Borówno, 21-Sobiejuskie, 22-Czarne, 23-NiskieBrodno, 24-BytyńWielki, 25-Iławskie, 26-Sendeńskie, 27-Górskie, 28-Wąsoskie, 29-Sosno, 30-Soczewka.

$51.2 \%$ (with the total infection of $32.4 \%$ ) and from $19.8 \%$ to $64.8 \%$ (with the total infection of $35.7 \%$ ) per lake, respectively (Fig. 2). There was no correlation in the infection of all the digenean species between the lakes inhabited and uninhabited by $P$. antipodarum $\left(p=-0.21, \mathrm{t}_{28}=1.13, p=0.270\right)$.

Seventeen species of digenean trematodes were found. The Shannon index showed no difference between the studied groups of water reservoirs in terms of the parasite species diversity (Tab. 2).

A significant difference in the number of reservoirs inhabited by snails infected with bird schistosomes was determined in the studied groups of water bodies (Fig. $2 ; \chi^{2}=5.43 ; \mathrm{df}=1 ; p=0.02$ ). The bird schistosome infection was found in five lakes inhabited and 11 lakes uninhabited by P. antipodarum. The total infection of bird schistosomes was $1.4 \%$ in L. stagnalis from all the investigated water bodies, $0.3 \%$ from the lakes inhabited and $2.2 \%$ from the lakes uninhabited by $P$. antipodarum. Their prevalence ranged from 0 up to $1.2 \%$ and from 0 upto $10 \%$ in the lakes inhabited and uninhabited by $P$. antipodarum, respectively (Fig. 2), and was negatively correlated with NZMS density $\left(\mathrm{p}=-0.47, \mathrm{t}_{28}=2.83, P=0.009\right)$ (Fig. 2).

\section{Discussion}

The presence of $P$. antipodarum in the lakes did not significantly affect the total digenean trematodes infection of the L. stagnalis populations; only in five out of 13 lakes the infection prevalence exceeded $30 \%$, while in the lakes not inhabited by the alien snail species more than $30 \%$ infection was recorded in nine out of 17 subjects (Fig. 2). Given that themiracidia of flukes use chemoreception to find the snail host (Haas et al., 1995), it should be assumed that the chemoreception efficiency of most of the detected parasite species was high, regardless of the presence of $P$. antipodarum in the environment.

The Shannon diversity index of trematode parasiteswas similar in both types of lakes, and the only bird schistosome species found was Trichobilharzi aszidati (Neuhaus, 1952). However, it is noteworthy that $T$. szidati-infected snails were mainly present in the lakes uninhabited by $P$. antipodarum (Fig. 2). The similar physicochemical and biocenotic conditions in both groups of lakes (SM 1) suggest that the presence of $P$. antipodarum may be an important factor differentiating the occurrence of T. szidati larvae in L. stagnalis populations. The prevalence of the parasite in the host snailswith one exception did not exceed $5.5 \%$. A small number of snails infected with bird schistosome in the studied lakes was in line with several earlier studies (Loy and Haas, 2001; Żbikowska, 2004; Jouet et al., 2008; Horák et al., 2015). It cannot be ruled out that the presence of non-host snail species in the environment generally disturbs the transmission of bird schistosome affecting a very low prevalence of the parasite. However, a high density of $P$. antipodarum populations could significantly disturb thistransmission. The fact that snails infected with $T$. szidati originated mainly from the lakes uninhabited by $P$. antipodarum may be due to the disturbance in the chemokinetic reaction of its miracidia by substances from the alien occurring at high population densities. The 
Table 2. Species diversity of Digenea in the studied populations of Lymnaea stagnalis.

\begin{tabular}{llc}
\hline Parasite & \multicolumn{2}{c}{ Number of lakes with infected L. stagnalis } \\
\cline { 2 - 3 } & Uninhabited by P. antipodarum* & Inhabited by P. antipodarum** \\
\hline Diplostomum pseudospathaceum & 17 & 13 \\
Echinoparyphium aconiatum & 17 & 13 \\
Plagiorchis elegans & 16 & 12 \\
Opisthioglyphe ranae & 16 & 6 \\
Echinostoma revolutum & 13 & 5 \\
Plagiorchis maculosus & 9 & 9 \\
Sanguinicola inermis & 6 & 9 \\
Notocotylus attenuatus & 7 & 11 \\
Hypoderaeum conoideum & 8 & 7 \\
Tylodelphys clavata & 4 & 5 \\
Australpatemon burti & 5 & 5 \\
Paryphostomum sp. & 3 & 11 \\
Trichobilharzia szidati & 5 & 5 \\
Neoglyphe sobolevi & 3 & 0 \\
Asymphylodora tincae & 2 & 1 \\
Echinoparyphium recurvatum & 1 & 1 \\
Xiphidiocercaria C & 1 & 5 \\
\hline
\end{tabular}

${ }^{*}$ Shannon-Wiener Index $\mathrm{H}^{\prime}=4.02$.

** Shannon-Wiener Index H'=3.92

complicated behaviour of schistosome miracidia was studied in the 1960s by MacInnis (1965) and Wright and Ross (1966). The further research on testing of signal compounds has revealed that attractants for parasite larvae include both hostderived and non-host molecules (Allan et al., 2009). Marszewska et al. (2020) found that excretory-secretory products derived from $P$. antipodarum effectively disrupt the chemokinetic reaction of $T$. szidati miracidia. Given that miracidia have only one attempt in adhesion to the signal source (Haas et al., 1995), the contact of larvae with the wrong target (i.e., P. antipodarum) irreversibly ends the transmission of the parasite. Miracidia within an incompatible snail are eliminated by its hemocytes and/or plasma factors (Bayne et al., 2001). In addition, it has been experimentally confirmed that the effect of $P$. antipodarum on the reduction of bird schistosomes prevalence increases as $P$. antipodarum density also increases (Marszewska et al., 2018). They examined the effectiveness of $T$. regenti invasion into Radix balthica (Linnaeus, 1758) (Gastropoda, Basommatophora, Lymnaeidae) co-occurring with the growing density of $P$. antipodarum populations.

On the other hand, Loy and Haas (2001), Żbikowska (2004), Jouet et al. (2008), and Horák et al. (2015)have agreed that even the low prevalence of the patent invasion of bird schistosomes in the host snail populations is a real threat of swimmer's itch for humans. This opinion has been based on the high productivity of cercariae inside an infected individual of snail (Horák et al., 2015), as well as on the observation that most infections are recorded during the summer, when recreational water use is highest (Żbikowska, 2004).

Previous laboratory tests showed that the average number of cercariae released from one snail per (one) day exceeded even 1800 larvae (Żbikowska and Marszewska, 2018). The effectiveness of attacks of bird schistosomecercariae on humans was also high. Żbikowska et al. (2001) presented in detail the changes on the researcher's skin resulting from the penetration of a single or several cercariae during the collection of the field samples.

In light of the results obtained, suggestions for the use of the non-host species of snails for the biological control of parasites seems to be well justified. Of course, introducing non-native species even only on bathing waters requires a detailed analysis of the potential consequences. In the case of Schistosoma mansoni, which is responsible for severe human schistosomiasis, this control model exhibited the expected effects (Pointier et al., 2011). In the case of threat of swimmer's itch, the decrease in the prevalence of parasites due to the intentional introduction of nonhost $P$. antipodarum into the bathing areas seems to be the form of protection that is worth considering. However, the ecological safety of such activities must be carefully examined and is the subject of ongoing research.

\section{Conflict of interest}

None of the authors of this paper has a financial or personal relationship with other people or organizations that could inappropriately influence or bias the content of the paper

\section{Supplementary Material}

SM 1 Table. Bottom type and biocenotic characteristics of sampling sites.

SM 2 Figure. Microscopical picture of the Trichobilharzia szidati cercaria.

The Supplementary Material is available at https://www.kmaejournal.org/10.1051/kmae/2021014/olm.

Acknowledgements. This project was supported by the Biological and Veterinary Sciences of Nicolaus Copernicus University [statutory fund research], the Scholarships for PhD students ZPORR - No. SPS.IV.0724-431/2010, and the grant of the National Science Centre, Poland No. 2017/25/N/NZ8/01345. 
We would like to thank Paola Lombardo for proofreading an English version of the manuscript.

\section{References}

Allan F, Rollinson D, Smith JE, Dunn AM. 2009. Host choice and penetration by Schistosoma haematobium miracidia. J Helminthol 83: 33-38.

Alonso A, Castro-Díez P. 2008. What explains the invading success of the aquatic mud snail Potamopyrgus antipodarum (Hydrobiidae, Mollusca)? Hydrobiologia 614: 107-116.

Arumugam A, Li J, Krishnamurthy P, Jia ZX, Leng Z, Ramasamy N, Du D. 2020. Investigation of toxic elements in Carassius gibelio and Sinanodonta woodiana and its health risk to humans. Environ Sci Pollut Res Int 27: 30901-30902.

Bayne CJ, Hahn UK, Bender RC. 2001. Mechanisms of molluscan host resistance and of parasite strategies for survival. Parasitology 123: 59-67.

Blankespoor HD, Reimink RL, 1991. The control of swimmer's itch in Michigan: past, present future. Mich Acad 24: 7-23.

Brown KM, Lang B, Perez KE. 2008. The conservation ecology of North American pleurocerid and hydrobiid gastropods. $J \mathrm{~N} \mathrm{Am}$ Benthol Soc 27: 484-495.

Brown KM, Leathers BK, Minchella DJ. 1988. Trematode prevalence and the population dynamics of freshwater pond snails. Am Midl Nat 120: 289-301.

Braun L, Grimes JET, Templeton MR. 2018. The effectiveness of water treatmentprocesses against schistosome cercariae: a systematic review. PLOS Negl Trop Dis 12: e0006364.

Caron Y, Cabaraux A, Marechal F, Losson B. 2017. Swimmer's itch in Belgium: first recorded outbreaks, molecular identification of the parasite species and intermediate hosts. Vector Borne Zoonotic Dis 17: 190-194.

Cichy A, Marszewska A, Parzonko J, Żbikowski J, Żbikowski E. 2017. Infection of Potamopyrgus antipodarum (Gray, 1843) (Gastropoda: Tateidae) by trematodes in Poland, including the first record of aspidogastrid acquisition. J Invertebr Pathol 150: 32-34.

Cichy A, Żbikowska E. 2016. Atlas of Digenea developmental stages: the morphological characteristics and spread within the populations of freshwater snails from the Brodnickie Lakeland, Poland. Wydawnictwo Naukowe Uniwersytetu Mikołaja Kopernika, Torun, 218p.

Civitello JD, Cohen J, Fatima H, Halstead NT, Liriano J, McMahon TA, Ortega CN, Sauer EL, Sehgal T, Young S, Rohr JR. 2015. PNAS 112: 8667-8671.

Da Silva A, Vinicios M, Nunes Souza JV, Souza JRB de, Vieira LM. 2019. Modelling species distributions to predict areas at risk of invasion by the exotic aquatic New Zealand mudsnail Potamopyrgus antipodarum (Gray 1843). Freshw Biol 64: 1504-1518.

Davidson T, Brenneis V, Rivera C de, Draheim R, Gillespie G. 2008. Northern range expansion and coastal occurrences of the New Zealand mud snail (Potamopyrgus antipodarum Gray, 1843) in the northeast Pacific. Aquat Invasions 3: 349-353.

Dorgelo J, van der Geest HG, Hunting ER. 2014. Dynamics of natural populations of the dertitivorous mudsnail Potamopyrgus antipodarum (Gray) (Hydrobiidae) in two interconnected Lakes differing in trophic state. Springer Plus 3: 736.

Gérard C, Blanc A, Costil K. 2003. Potamopyrgus antipodarum (Mollusca: Hydrobiidae) in continental aquatic gastropod communities: impact of salinity and trematode parasitism. Hydrobiologia 493: 167-172.
Goedknegt MA, Nauta R, Markovic M, Buschbaum C, Folmer EO, Luttikhuizen PC, van der Meer J, Waser AM, Wegner KM, Thieltges DW. 2019. How invasive oysters can affect parasite infection patterns in native mussels on a large spatial scale. Oecologia 190: 99-113.

Goodenough A. 2010. Are the ecological impacts of alien species misrepresented? A review of the native good, alien bad philosophy. Community Ecol 11: 13-21.

Haas W, Haberl B, Kalbe M, Kömer M, 1995. Snail-host-finding by Miracidia and Cercariae: chemical hst cues. Parasitol Today 11: 468-472.

Hall RO, Tank JL, Dybdahl MF. 2003. Exotic snails dominate nitrogen and carbon cycling in a highly productive stream. Front Ecol Environ 1: 407-411.

Hammer Ø, Harper DAT, Ryan PD. 2001. Past: Paleontological statistic software package for education and data analysis. Palaeontol Electron 4: 1-9.

Hechinger RF. 2012. Faunal survey and identification key for the trematodes (Platyhelminthes: Digenea) infecting Potamopyrgus antipodarum (Gastropoda: Hydrobiidae) as first intermediate host. Zootaxa 3418: 1.

Horák P, Mikeš L, Lichtenbergová L, Skála V, Soldánová M, Brant SV. 2015. Avian schistosomes and outbreaks of cercarial dermatitis. Clin Microbiol Rev 28: 165-190.

Huot C, Clerissi C, Gourbal B, Galinier R, Duval D, Toulza E. 2020. Schistosomiasis vector snails and their microbiota display a phylosymbiosis pattern. Front Microbiol 10: 3092

Jermacz Ł, Nowakowska A, Kletkiewicz H, Kobak J. 2020. Experimental evidence for the adaptive response of aquatic invertebrates to chronic predation risk. Oecologia 192: 341-350.

Johnson PTJ, Thieltges DW. 2010. Diversity, decoys and the dilution effect: howecological communities affect disease risk. J Exp Biol 213: 961-970.

Johnson TJ, Lund PJ, Hartson RB, Yoshino TP. 2009. Community diversityreduces Schistosoma mansoni transmission, host pathology and human infection risk. Proc Royal Soc B 276: $1657-1663$.

Jouet D, Ferté H, Depaquit J, Rudolfová J, Latour P, Zanella D, Kaltenbach ML, Léger N. 2008. Trichobilharzia spp. in natural conditions in Annecy Lake, France. Parasitol Res 103: 51-58.

Keesing F, Holt RD, Ostfeld RS. 2006. Effects of species diversity on disease risk. Ecol Lett 9: 485-498.

Kerans BL, Dybdahl MF, Gangloff MM, Jannot JE. 2005. Potamopyrgus antipodarum: distribution, density, and effects on native macroinvertebrate assemblages in the Greater Yellowstone Ecosystem. J N Am Benthol Soc 24: 123-138.

King CH, Bertsch D. 2015. Historical perspective: Snail control to prevent schistosomiasis. PLoS Negl Trop Dis 9: e0003657.

King KC, Delph LF, Jokela J, Lively CM. 2011. Coevolutionary hotspots and coldspots for host sex and parasite local adaptation in a snail-trematode interaction. Oikos 120: 1335-1340.

Kondakov AV, Konopleva ES, Vikhrev IV, Bespalaya YV, Gofarov MY, Kabakov MV, Tomilova AA, Vinarski MV, Bolotov IN. 2020. Phylogeographic affinities, distribution and population status of the non-native Asian pond mussels Sinanodonta lauta and $S$. woodiana in Kazakhstan. Ecol Mont 27: 22-34.

Kopp K, Jokela J. 2007. Resistant invaders can convey benefits to native species. Oikos 116: 295-301.

Larson MD, Dewey JC, Krist AC. 2020. Invasive Potamopyrgus antipodarum (New Zealand mud snails) and native snails differ in sensitivity to specific electrical conductivity and cations. Aquat Ecol 54: 103-117. 
Larson MD, Krist AC. 2020. Trematode prevalence and an invasive freshwater snail: fewer infections and parasites likely contribute to the success of an invasive snail. Biol Invasions 22: 1279-1287.

Lawton SP, Lim RM, Dukes JP, Cook RT, Walker AJ, Kirk RS. 2014. Identification of a major causative agent of human cercarial dermatitis, Trichobilharzia franki (Müller and Kimmig 1994), in southern England and its evolutionary relationships with other European populations. Parasites Vectors 7: 277.

Levri EP, Kelly AA, Love E. 2007. The Invasive New Zealand mud snail (Potamopyrgus antipodarum) in Lake Erie. J Great Lakes Res 33: 1-6.

Liberato $\mathrm{C}$ de, Berrilli $\mathrm{F}$, Bossù $\mathrm{T}$, Magliano A, Di Montalbano Filippo M, Di Cave D, Sigismondi M, Cannavacciuolo A, Scaramozzino P. 2019. Outbreak of swimmer's itch in Central Italy: Description, causative agent and preventive measures. Zoonoses Public Health 66: 377-381.

Lively CM. 1987. Evidence from a New Zealand snail for the maintenance of sex by parasitism. Nature 328: 519-521.

Loy C, Haas W. 2001. Prevalence of cercariae from Lymnaea stagnalis snails in a pond system in Southern Germany. Parasitol Res 87: 878-882.

Lysne S, Koetsier P. 2008. Comparison of desert valvata snail growth at three densities of the invasive New Zealand mudsnail. West $N \mathrm{Am}$ Nat 68: 103-106.

MacInnis AJ. 1965. Responses of Schistosoma mansoni miracidia to chemical attractants. $J$ Parasitol 51: 731.

Marszewska A, Cichy A, Bulantová J, Horák P, Żbikowska E. 2018. Potamopyrgus antipodarum as a potential defender against swimmer's itch in European recreational water bodies-experimental study. PeerJ 6: e5045.

Marszewska A, Cichy A, Bulantová J, Horák P, Żbikowska E. 2020. The chemotactic swimming behavior of bird schistosome miracidia in the presence of compatible and incompatible snail hosts. Peer J. 8: e9487.

Marszewska A, Cichy A, Heese T, Żbikowska E. 2016. The real threat of swimmers' itch in anthropogenic recreational water body of the Polish Lowland. Parasitol Res 115: 3049-3056.

Moffitt C, James C. 2012. Dynamics of Potamopyrgus antipodarum infestations and seasonal water temperatures in a heavily used recreational watershed in intermountain North America. Aquat Invasions 7 193-202.

Morley NJ. 2008. The role of the invasive snail Potamopyrgus antipodarum in the transmission of trematode parasites in Europe and its implications for ecotoxicological studies. Aquat Sci 70: 107-114.
Nelwan ML. 2019. Schistosomiasis: life cycle, diagnosis, and control. Curr Ther Res 91: 5-9.

Pointier JP, Jourdane J. 2000. Biological control of the snail hosts of schistosomiasis inareas of low transmission: the example of the Caribbean area. Acta Tropica 77: 53-60.

Pointier JP, David P, Jarne P. 2011. The biological control of the snail hosts of Schistosomes: the role of competitor snails and biological invasions. In Toledo R, Fried B, eds. Biomphalaria Snails and Larval Trematodes. New York: Springer, pp. 215-238.

Rachalewski M. 2019. Friends or enemies? Chemical recognition and reciprocal responses among invasive Ponto-Caspian amphipods. Aquat Invasions 14: 667-683.

Selbach C, Soldánová M, Sures B. 2016. Estimating the risk of swimmer's itch in surface waters - a case study from Lake Baldeney, River Ruhr. Int J Hyg Environ Health 219: 693-699.

Soldánová M, Selbach C, Kalbe M, Kostadinova A, Sures B. 2013. Swimmer's itch: etiology, impact, and risk factors in Europe. Trends Parasitol 29: 65-74.

Thieltges DW, Jensen KT, Poulin R. 2008. The role of biotic factors in thetransmission of free-living endohelminth stages. Parasitology 135: 407-426.

Tracz ES, Al-Jubury A, Buchmann K, Bygum A. 2019. Outbreak of Swimmer's Itch in Denmark. Acta Derm Venereol 99: 1116-1120.

Winterbourn MJ. 1973. A guide to the freshwater mollusca of New Zealand. Tuatara 20: 141-159.

Winterbourn MJ. 1974. Trematode parasitizing the New Zealand species of Potamopyrgus (Gastropoda: Hydrobiidae). Mauri Ora 2: $17-30$.

Wright CA, Ross GC. 1966. Electrophoretic studies on planorbid eggproteins. The Bulinus africanus and B. forskalii species groups. Bulletin World Health Organ 35: 727-731.

Żbikowska E. 2004. Infection of snails with bird schistosomes and the threat of swimmer's itch in selected Polish lakes. Parasito Res 92: $30-35$.

Żbikowska E, Franckiewicz-Grygon B, Wójcik AR. 2001. Przypadek dermatitis u człowieka wywołany przez cerkarie ptasich schistosom. Wiad Parazyt 47: 427-431.

Żbikowska E, Marszewska A. 2018. Thermal preferences of bird schistosome snail hosts increase the risk of swimmer's itch. $J$ Thermal Biol 78: 22-26.

Żbikowski J, Żbikowska E. 2009. Invaders of an invader-trematodes in Potamopyrgus antipodarum in Poland. J Invertebr Pathol 101: $67-70$.

Cite this article as: Żbikowska E, Stanicka A, Cichy A, Żbikowski J. 2021. Can Potamopyrgus antipodarum (Gastropoda) affect the prevalence of Trichobilharzia szidati in Lymnaea stagnalis populations? Knowl. Manag. Aquat. Ecosyst., $422,15$. 